\title{
Residential Building Evacuation-Simulation of Potential Evacuation Scenarios With Presence of Immobile Persons
}

\author{
RADOJE B. JEVTIĆ, Electrotechnical school „Nikola Tesla“, Niš
}

\author{
Professional paper \\ UDC: 614.8 .084 \\ DOI: 10.5937/tehnika2006814J
}

\begin{abstract}
The increase in urban population leads to the lack of housing in cities. One of potential solutions for this problem is to build tall residential buildings. The height of this objects, in recent times, ranges from several tens of meters even to several hundreds of meters, while the number of residents ranges from several hundred even to several thousands. Although these objects have built related to modern standards and technologies, with usage of modern materials and machines, problems can happen. One of particularly complex and hard problem presents the evacuation of residents in case of some disaster. Problem is much more severe and complicated if there are people with disabilities or people with special needs in the building. The potential solution for this problem can be the usage of simulation software. This paper was written to show the usage of simulation software Pathfinder in calculation of evacuation times for different evacuation scenarios, without the presence of immobile occupants, with presence of immobile occupants in the percentage of $5 \%$ from complete occupant's number and with presence of immobile occupants in the percentage of $10 \%$ from complete occupant's number.
\end{abstract}

Key words: evacuation, residential, immobile, scenario

\section{INTRODUCTION}

High residential buildings present the past, the present and the future of residential architecture. The increase of population and migrations to cities has led to rapid lack of space. These lacks of space and overcrowding in big cities have been started to present modern and always open problem. Huge number of people, concentrated in limited space, where they should work and live can slow down or even completely stop functioning of the city. So, the potential logic solution has been found in the construction of tall residential buildings. Design, construction and realisation of those objects purport sublimation of huge knowledge, technologies and experience. Modern high residential buildings present residential objects, energy effective, with all possible solutions that their residents can live safely and cosy inside. But, history and statistic showed that the safest buildings at certain times and cases can become unsafe and that many of their residents can be killed.

Authors'address: Radoje Jevtić, Electrotechnical school „Nikola Tesla“, Niš. Aleksandra Medvedeva 18

e-mail: milan.jvtc@gmail.com

Paper received: 20.11.2020.

Paper accepted: 27.11.2020.
The advancement of science, the usage of many new technics and materials has led to the advancement in architecture, unthinkable before. One of the tallest residential buildings in the world for a long time (in the period from 1931 to 1972) was famous Empire State Building, in New York, USA.

The height of this building is 443 meters and has 102 floors. This building was designed by Shreve, Lamb and Herman architects. According to some evaluations, the complete price of the building was 555 million in 2018 USA dollars [1, 2].

From that time, till today, the number of people on the Earth increased to today`s huge 7 billion and 772 million. One of the consequences was the building of many tall residential, but also and other types of buildings.

The heights of residential buildings were constantly increasing. In 2000, the tallest residential buildings were the Belcher's Tower 1 and 2, located in Hong Kong. Their heights were equal to 221 metres. In 2001, the Trump World Tower became the tallest residential building in the world.

In 2003, that was 21st Century Tower in Dubai. The residential buildings with height taller than 200 meters increased from $34 \%$ in 2009 , up to $45 \%$ in 2010. 
At this moment, the tallest residential building in the world is Burj Khalifa, also known as Burj Dubai with unbelievable 828 meters. But, this structure is not clear residential building. Beside residential space, this building possesses business space, hotel space and other.

The list of the tallest residential building in the world is presented in table 1 [3].

Table 1. The list of the fifteen tallest residential building in the world (table source: https:/len.wikipedia.org/wiki/ List_of_tallest residential_buildings)

\begin{tabular}{|c|c|c|c|c|c|c|}
\hline Rank & Name & City & Country & Height [m] & Floors & Finished year \\
\hline 1. & $\begin{array}{l}\text { Central Park } \\
\text { Tower }\end{array}$ & New York City & USA & 472 & 98 & 2020 \\
\hline 2. & $\begin{array}{l}111 \text { West } 57 \text { th } \\
\text { Street }\end{array}$ & New York City & USA & 432 & 82 & 2020 \\
\hline 3. & 432 Park Avenue & New York City & USA & 425.5 & 88 & 2015 \\
\hline 4. & Princess Tower & Dubai & United Arab Emirates & 413 & 101 & 2012 \\
\hline 5. & 23 Marina & Dubai & United Arab Emirates & 392 & 90 & 2012 \\
\hline 6. & Elite Residence & Dubai & United Arab Emirates & 381 & 91 & 2012 \\
\hline 7. & Marina Torch & Dubai & United Arab Emirates & 352 & 80 & 2012 \\
\hline 8. & Neva Towers 2 & Moscow & Russia & 345 & 79 & 2020 \\
\hline 9. & Q1 & Gold Coast & Australia & 322 & 80 & 2005 \\
\hline 10. & HHHR Tower & Dubai & United Arab Emirates & 317 & 72 & 2009 \\
\hline 11. & Ocean Heights & Dubai & United Arab Emirates & 310 & 84 & 2010 \\
\hline 12. & Burj Rafal & Riyadh & Saudi Arabia & 308 & 68 & 2014 \\
\hline 13. & Cayan Tower & Dubai & United Arab Emirates & 306 & 76 & 2013 \\
\hline 14. & One57 & New York City & USA & 306 & 75 & 2014 \\
\hline 15. & Etihad Tower 2 & Abu Dhabi & United Arab Emirates & 305 & 80 & 2011 \\
\hline
\end{tabular}

In Serbia, the tallest residential building is, so called, the Western Gate of Belgrade or Genex tower with height of 135 meters and 27 floors, built in 1980. After this residential building, there are three identical residential buildings, so called Eastern Gates of Belgrade or Rudo A, Rudo B and Rudo C with their heights of about 100 meters, built in 1976. After these buildings, with its 91 meters height, there are residential towers in Vojvode Stepe Street, built in 1976.

Next building is residential building in Niš, known as TV 5 building, with height of 85 meters, built in 1973. It is interesting that this building presents the tallest residential building in Niš and the tallest building out of Belgrade. It is also important to note that the tallest building in Serbia presents bussines center „Ušće“, which with antenna on the top of the building reaches 141 meters [4].

Tall residential buildings with solutions for accommodation of huge number of people brought new and always actual problem: how to safely evacuate that number of people in the case of human error, lack of property standards, some disaster like fire, earthquake, and terrorism attack or similar?
All around world, through history, tall residential buildings have cracked, split and crashed. Huge number of people was killed. Although they don't belong to the category of ,residential buildings", it is important to note that the most devastating building collapse in history-the case of Twin Towers in New York, in September 11, 2001. According to some sources, each tower weighted more than 500000 tones, while the number of victims was over 2600 people. On November 15, 2010, monsoon rains caused crashed of residential building in New Delhi, India. Related to some sources, 67 people died in the collapse while more than 150 were injured. In Shanghai, on June 27, 2009 , one of 13-story apartment buildings toppled over. It is also interesting to note the disaster occurred in East London, on May 16, 1968, where high residential building with 22 floors collapsed, with „only" four killed and 17 injured [5]. Of course, the limits of this paper don't allow noting all disasters in tall residential or other kind building, but is obvious that all tall buildings have one complex and always actual problem and that is the safe evacuation of residents. One of the most important things in evacuation is that occupants know what to do in the case of evacuation, where to go, how to behave and 
similar. Theoretically, it looks simply but in real, there are very often situations that can be occurred where panic, stress and fear cause total chaos and significantly increase the number of potential victims. It is obvious that prediction of potential evacuation scenario presents very hard, responsible and complex task. One of the best ways for evacuation prediction, in sense of safety, cheapness and protection, presents the usage of simulation software. Today, there are several computer simulation programs on the market. One of those computer programs is Pathfinder. This paper presents simulation of evacuation from tall residential building without presence of immobile occupants (residents), with presence of immobile occupants in the percentage of $5 \%$ from complete occupant's number and with presence of immobile occupants in the percentage of $10 \%$ from complete occupant's number in Pathfinder simulation software.

\section{PATHFINDER SIMULATION SOFTWARE}

Pathfinder presents very power software engineering tool for simulation of evacuation scenarios and calculation of evacuation times from objects with real dimensions. It is possible to simulate buildings with stairs, elevators, doors, and normal occupants, immobile occupants (in medical bed or in wheelchair) etc.

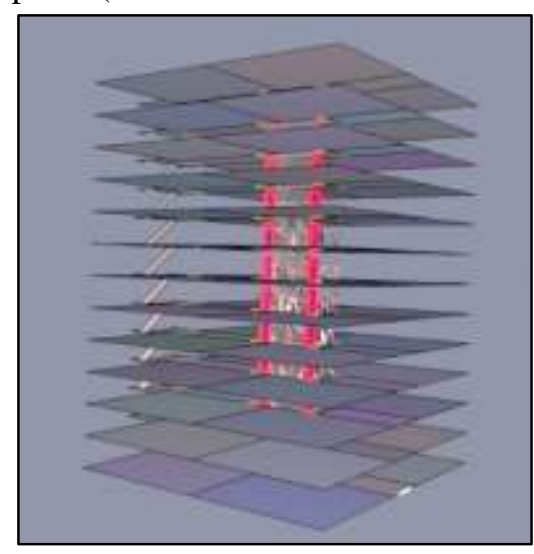

Figure 1 - Residential building in Pathfinder presentation-front and side view

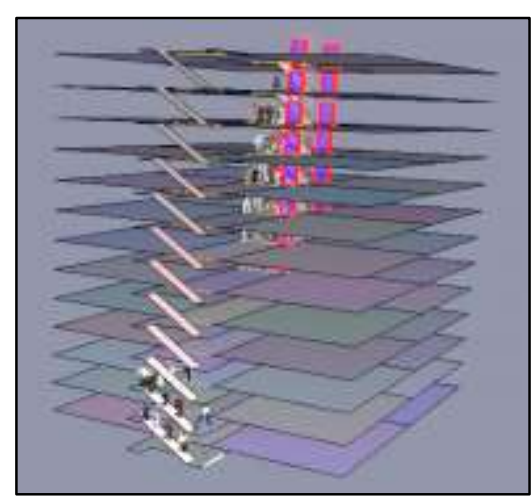

Figure 2 - Residential building in Pathfinder presentation-back view
Occupants in this simulation software were design with their dimensions, position in particular object and proper behaviour. Pathfinder simulation software enables using of two different types of movement: so called „steering” mode and so called „SFPE” mode. The first mode purports that occupants steer and interact with other occupants, while the second mode purports avoiding between occupants and existing of limits related to door`s flow and speed. Pathfinder, as every similar simulation software demands strong hardware configuration. Objects can be drawn directly in Pathfinder, but also can be imported from another graphic program, such as PyroSim, 3D CAD, FDS etc. From the moment when it had been published, there were several versions of this software. For the needs of this paper, version Pathfinder 2019 was used [6, 7]. Pathfinder presentation of residential building is presented on figures 1 and 2.

\section{SIMULATION MODEL}

Simulation model in this paper presents residential building with its real dimensions. The base of building presents square with approximate dimensions $17 \mathrm{~m} \mathrm{x}$ $17 \mathrm{~m}$ and twelve floors. The height between floors is $2.54 \mathrm{~m}$. Every floor has four flats, two with approximate surface of $70 \mathrm{~m}^{2}$ and two with approximate surface of $55 \mathrm{~m}^{2}$. Floors were connected with ordinary stairs, emergency stairs and elevators. The width of ordinary stairs was $1.25 \mathrm{~m}$, while the width of emergency stairs was $0.95 \mathrm{~m}$. There were two elevators for residents; one with capacity of four persons and one with capacity of eight persons. The speed of smaller elevator was from $1 \mathrm{~m} / \mathrm{s}$ to $1,3 \mathrm{~m} / \mathrm{s}$ and the speed of bigger elevator was from $0,6 \mathrm{~m} / \mathrm{s}$ to $0.9 \mathrm{~m} / \mathrm{s}$, in dependence of weight.

There were seven different evacuation scenarios realized. The first scenario purported that occupants could use elevators, ordinary stairs and fire stairs for evacuation. The second scenario purported that occupants could use elevators and ordinary stairs for evacuation. The third scenario purported that occupants could use elevators and fire stairs for evacuation. The fourth scenario purported that occupants could use ordinary stairs and fire stairs for evacuation. The fifth scenario purported that occupants could use only elevators for evacuation. The sixth scenario purported that occupants could use only ordinary stairs for evacuation. The seventh scenario purported that occupants could use only fire stairs for evacuation.

For every of seven scenarios, the speeds of occupants were $1.2 \mathrm{~m} / \mathrm{s}, 1.5 \mathrm{~m} / \mathrm{s}, 1.8 \mathrm{~m} / \mathrm{s}, 2.1 \mathrm{~m} / \mathrm{s}$ and 2.5 $\mathrm{m} / \mathrm{s}$. Immobile occupants were presented as wheelchairs and medical beds. The dimensions of wheelchair were $78 \mathrm{~cm} \times 50 \mathrm{~cm} \times 50 \mathrm{~cm}$, while the dimensions of medical bed were $200 \mathrm{~cm}$ x $90 \mathrm{~cm}$ x $75 \mathrm{~cm}$. Every 
wheelchair purported one or two occupants for assistance, in dependence of where it moves: in elevator, via ordinary stairs or via fire stairs, while medical bed purports two or four occupants for assistance, also in dependence of where it moves: in elevator, via ordinary stairs or via fire stairs. Speeds for wheelchairs were from $0.4 \mathrm{~m} / \mathrm{s}$ to $1.3 \mathrm{~m} / \mathrm{s}$, while speeds for medicals bed were from $0.2 \mathrm{~m} / \mathrm{s}$ to $1.2 \mathrm{~m} / \mathrm{s}$.

Every of seven scenarios purported three different cases: without immobile occupants, with $5 \%$ of immobile occupants randomly arranged (10 immobile occupants, 5 with wheelchairs and 5 with medical beds) and with $10 \%$ of immobile occupants randomly arranged (20 immobile occupants, 10 with wheelchairs and 10 with medical beds) $[8,9]$.

\section{SIMULATION RESULTS}

For realisation of simulation results, laptop DELL NOT15456 15, 6; processor Intel i5-1035G1 quad core; 8 GB DDR 4 RAM on $2666 \mathrm{MHz}$; 512 GB SSD hard disc and graphic card nVidia GeForce MX230 was used. Simulation software usually demands strong computer`s hardware configuration.

Due to the limitations of this paper, only some simulation moments on figures from 3 to 10 are presented, while complete simulation results for all seven scenarios, for every of three cases for each scenario are presented on figures 11 to 17 .

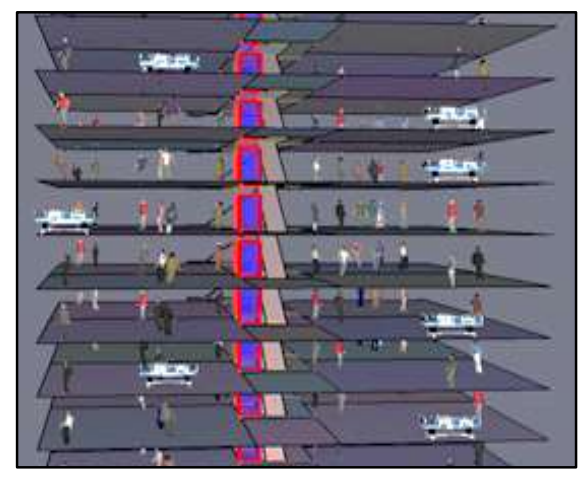

Figure 3 - Simulation moment for the first scenario and the third case.

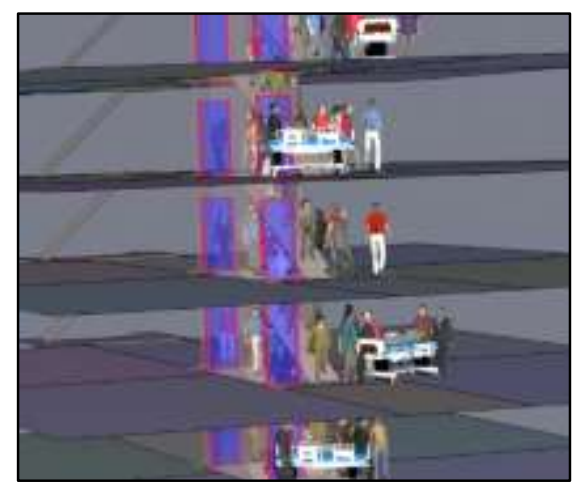

Figure 4 - Simulation moment for the first scenario and the second case.

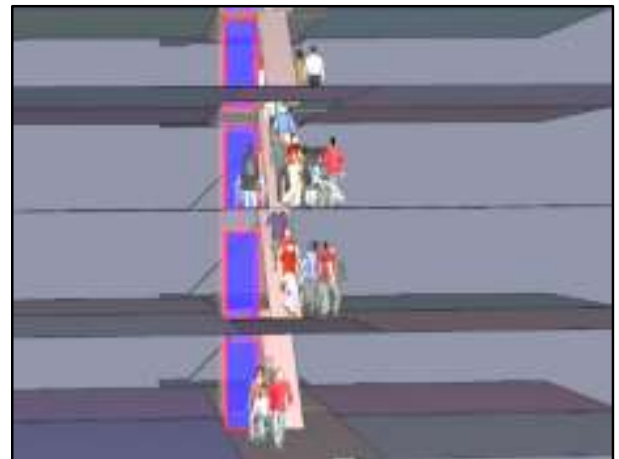

Figure 5 - Simulation moment for the second scenario and the second case.

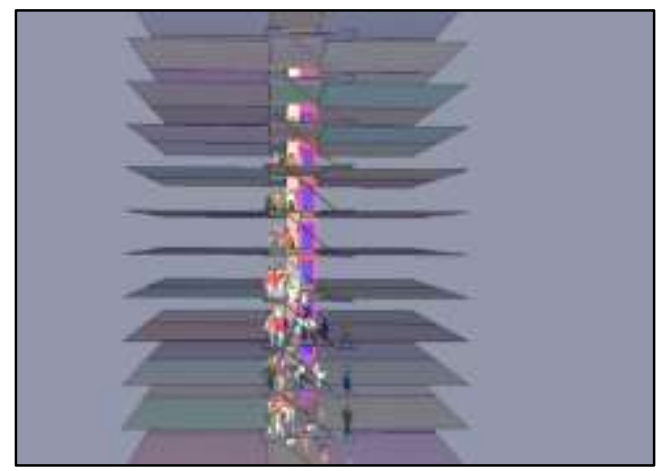

Figure 6 - Simulation moment for the fourth scenario and the third case.

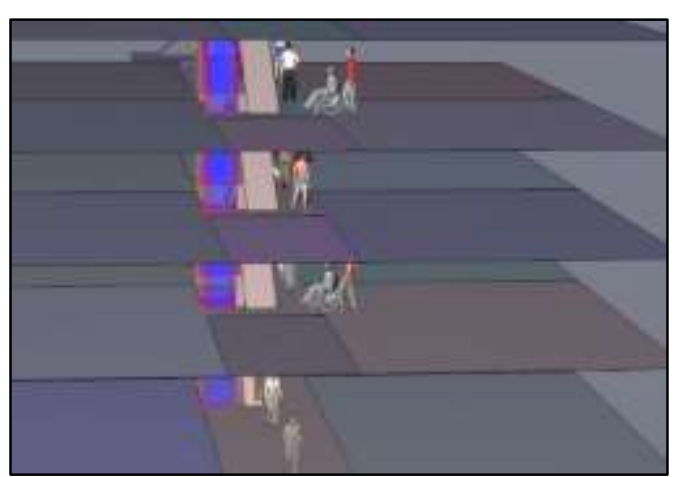

Figure 7 - Simulation moment for the fifth scenario and the second case.

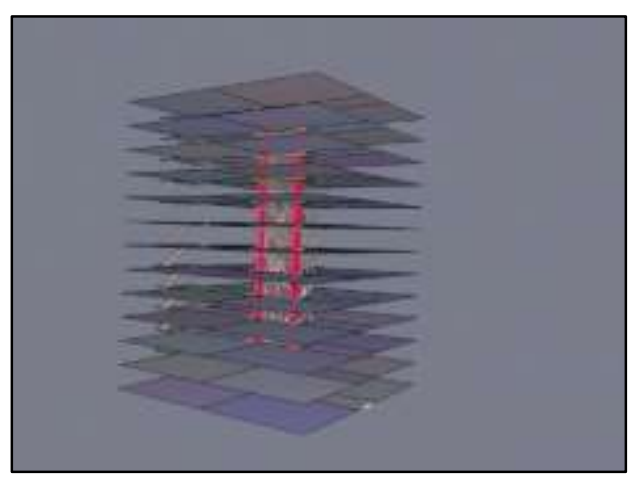

Figure 8 - Simulation moment for the sixth scenario and the first case. 


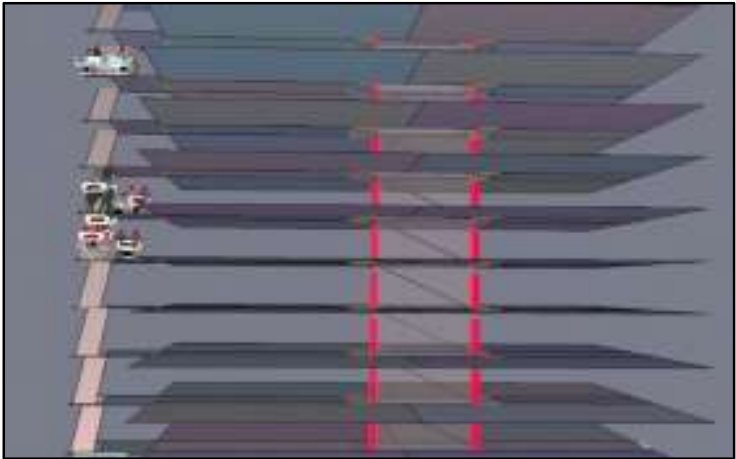

Figure 9 - Simulation moment for the seventh scenario and the second case.

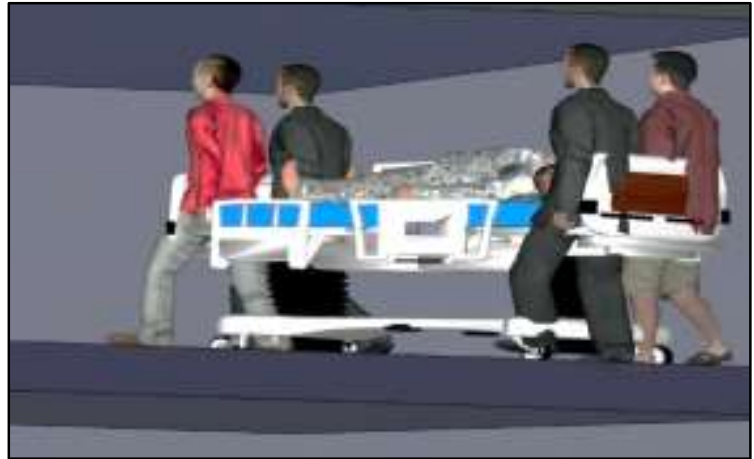

Figure 10 - Simulation moment for evacuation of immobile person in medical bed

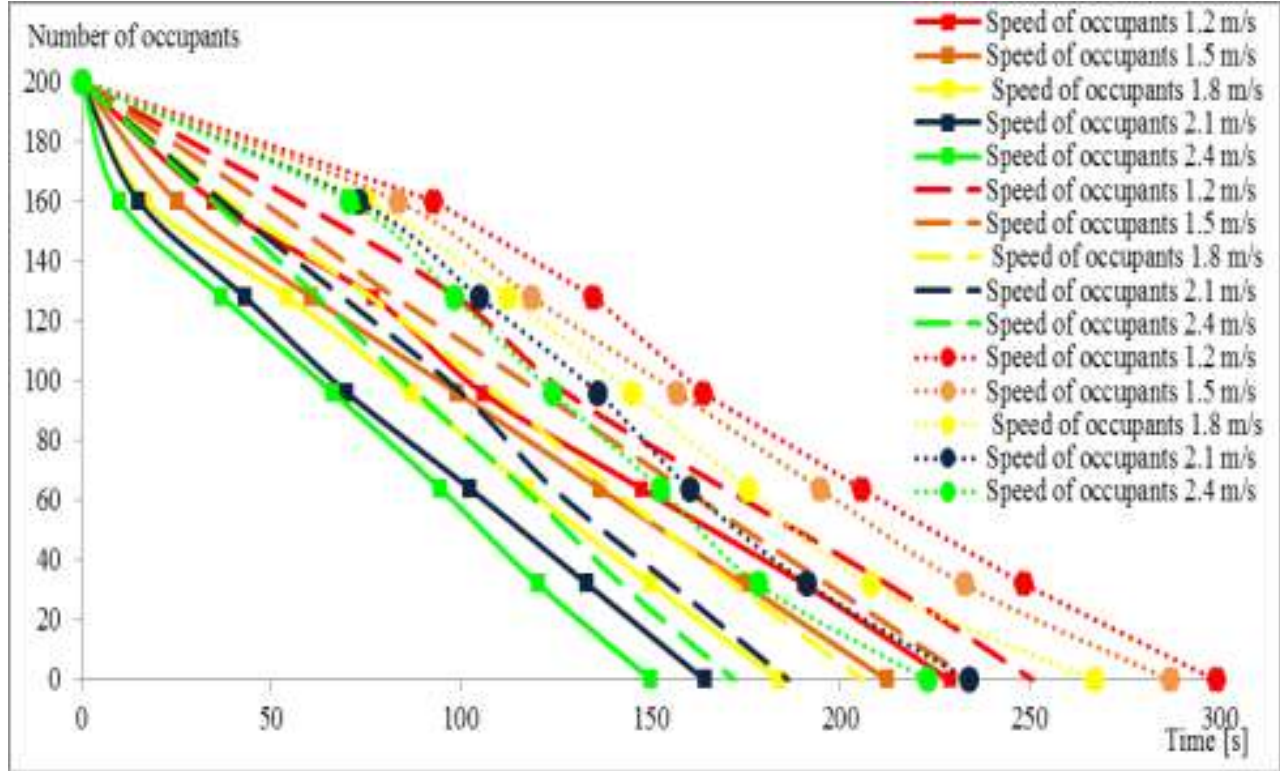

Figure 11 - Simulation results for the first scenario where elevators, ordinary stairs and emergency stairs were enabled (marks: ,- - " for the first case, , - - - " the second case, ," -••", for the third case)

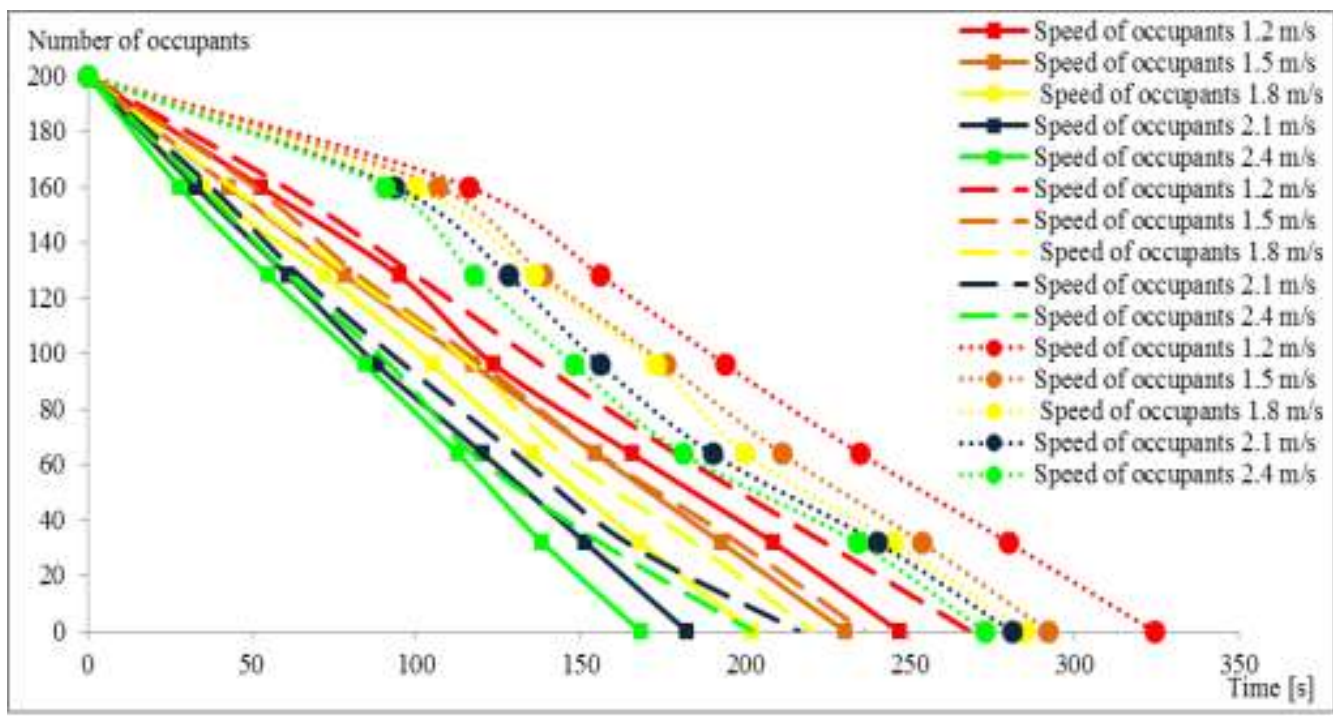

Figure 12 - Simulation results for the second scenario where elevators and ordinary stairs were enabled (marks:

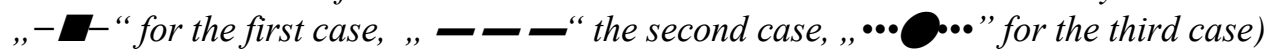




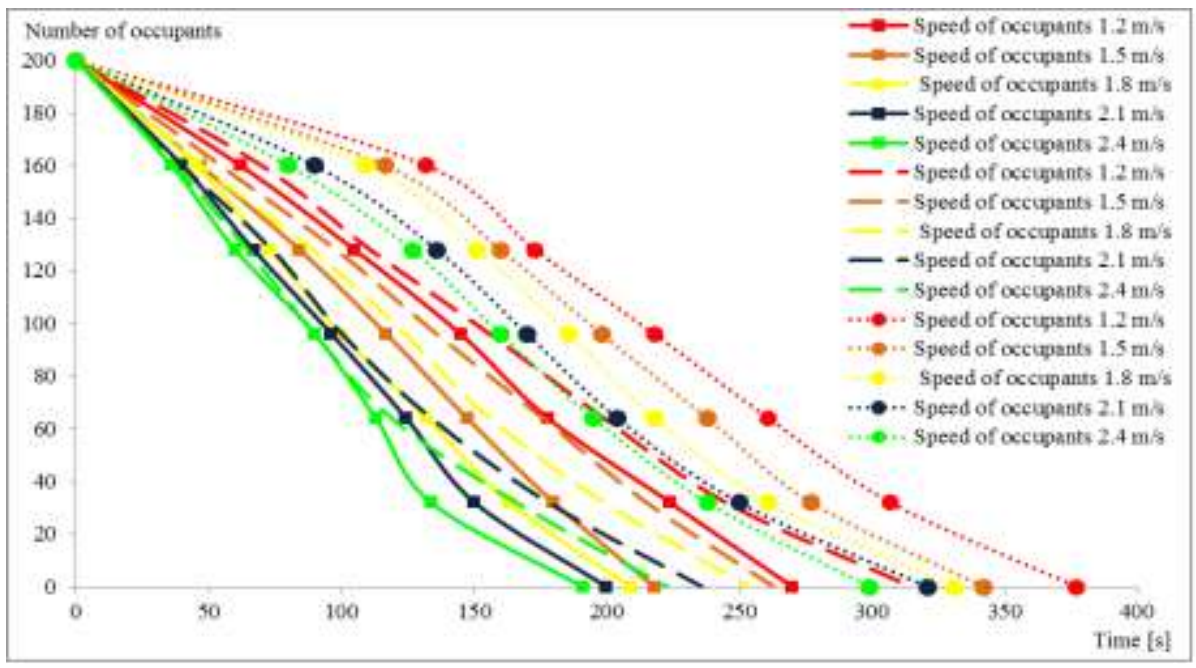

Figure 13 - Simulation results for the third scenario where elevators and emergency stairs were enabled (marks:

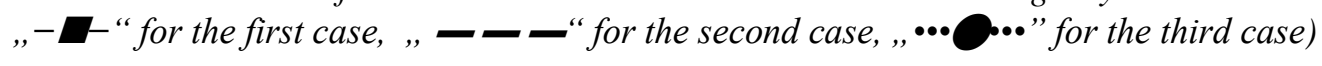

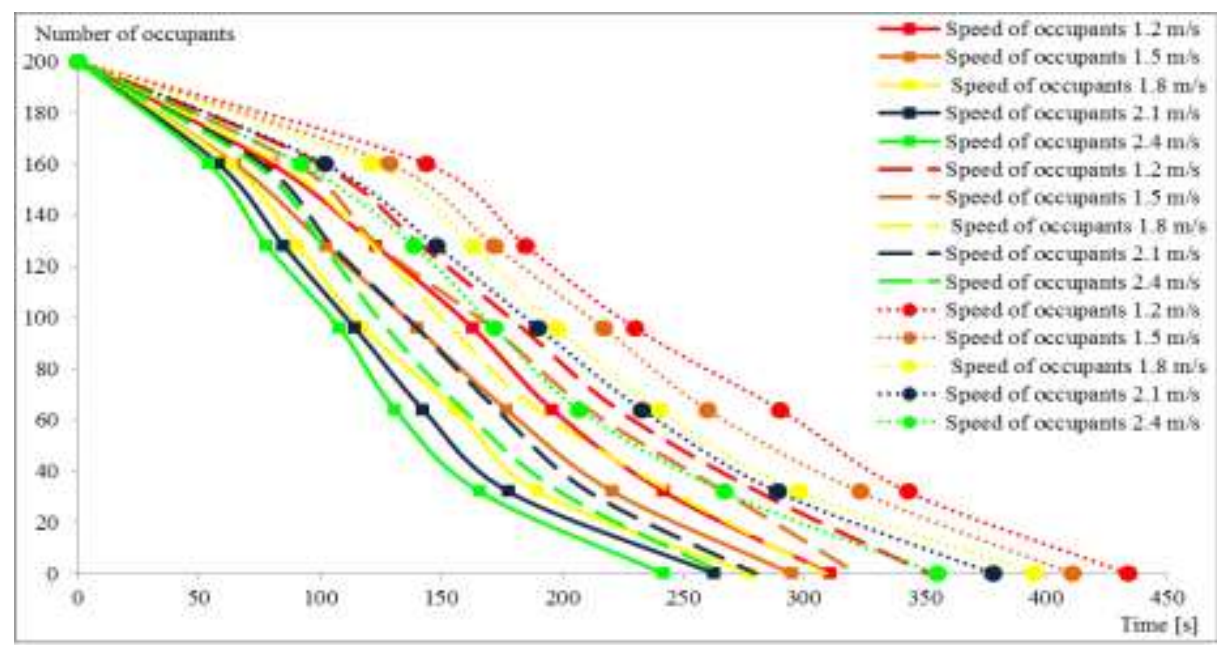

Figure 14 - Simulation results for the fourth scenario where ordinary stairs and emergency stairs were enabled (marks: ,,- - "for the first case, , - - - "for the second case, , ...

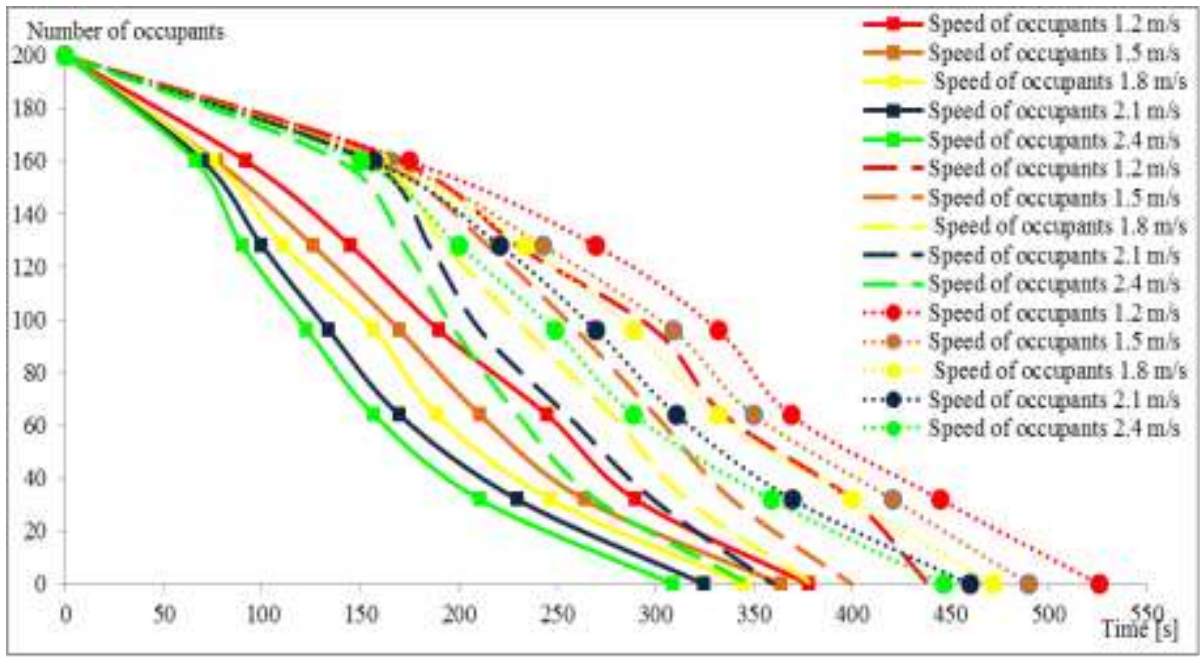

Figure 15 - Simulation results for the fifth scenario where only elevators were enabled (marks: ,- - - “ for the first case, , - - - for the second case, ,......” for the third case) 


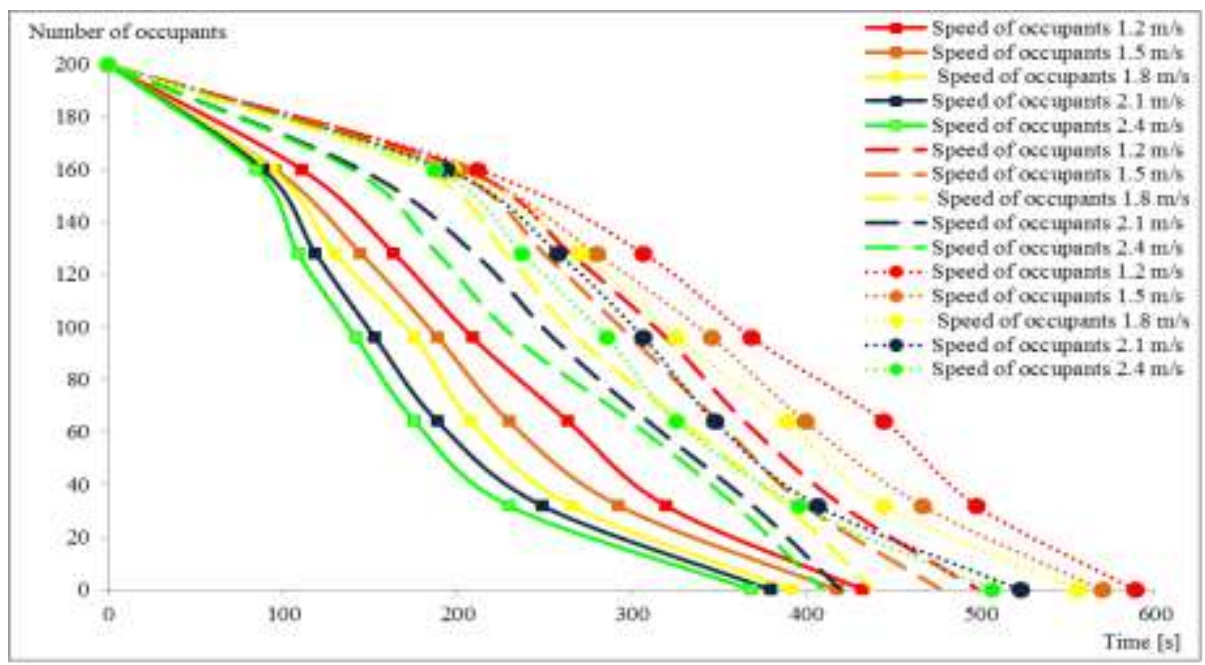

Figure 16 - Simulation results for the sixth scenario where only ordinary stairs were enabled (marks: „,- $\mathbf{-}$ “ for the first case, ,, - - - for the second case, , ,.-..” for the third case)

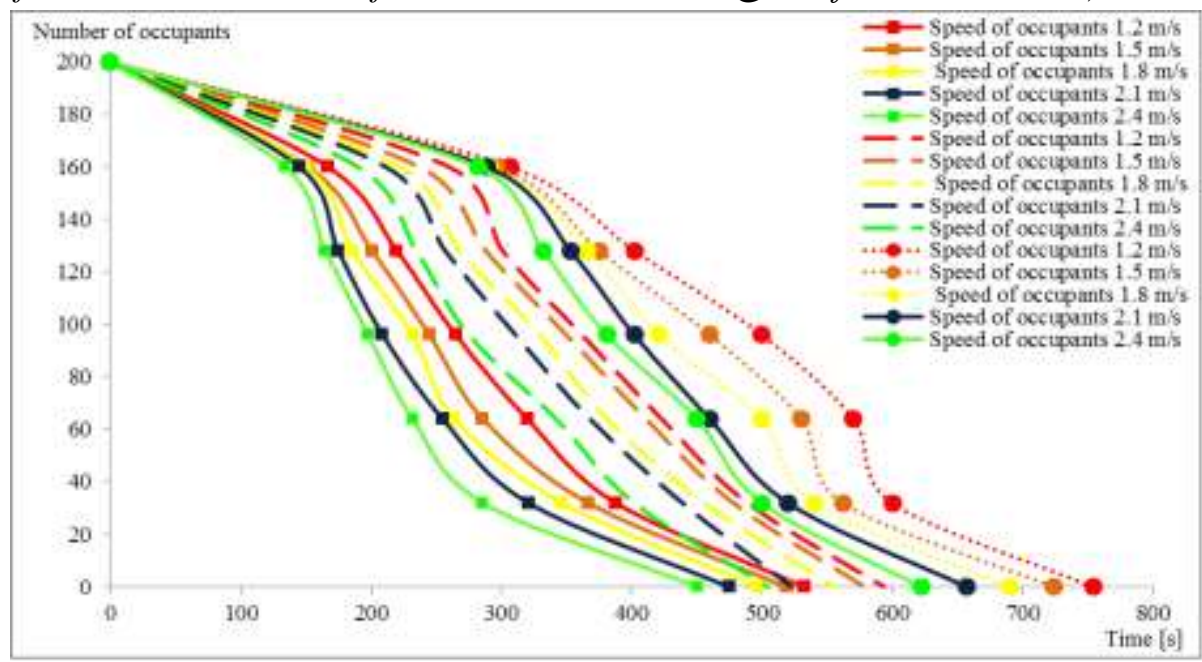

Figure 17 - Simulation results for the seventh scenario where only emergency stairs were enabled (marks:

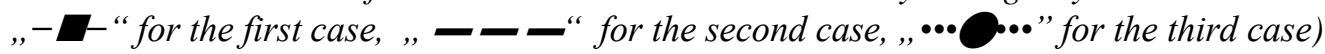

\section{RESULTS ANALYSE}

Results presented on figures from 11 to 17 showed evacuation times for every scenario and every of three cases included in scenario.

Realised results for the first scenario showed that the shortest time for evacuation was for the first case and occupant 's speed of $2.4 \mathrm{~m} / \mathrm{s}$ (150.2 seconds), while the longest evacuation time was for the third case and occupant's speed of $1.2 \mathrm{~m} / \mathrm{s}$ (299 seconds), as it was expected (figure 11). There were no signs of jams observed.

Realised results for the second scenario showed that the shortest time for evacuation was for the first case and occupant s speed of $2.4 \mathrm{~m} / \mathrm{s}$ (168.7 seconds), while the longest evacuation time was for the third case and occupant's speed of $1.2 \mathrm{~m} / \mathrm{s}$ (324.4 seconds), as it was expected (figure 12). There were no signs of jams observed.
Realised results for the third scenario showed that the shortest time for evacuation was for the first case and occupant's speed of $2.4 \mathrm{~m} / \mathrm{s}$ (191 seconds), while the longest evacuation time was for the third case and occupant's speed of $1.2 \mathrm{~m} / \mathrm{s}$ (377 seconds), as it was expected (figure 13). Mild signs of jams were observed.

Realised results for the fourth scenario showed that the shortest time for evacuation was for the first case and occupant s speed of $2.4 \mathrm{~m} / \mathrm{s}$ (242.7 seconds), while the longest evacuation time was for the third case and occupant's speed of $1.2 \mathrm{~m} / \mathrm{s}$ (434.3 seconds), as it was expected (figure 14). Signs of low intensity jams were observed, mostly when emergency stairs were used.

Realised results for the fifth scenario showed that the shortest time for evacuation was for the first case and occupant's speed of $2.4 \mathrm{~m} / \mathrm{s}$ (309 seconds), while the longest evacuation time was for the third case and 
occupant`s speed of $1.2 \mathrm{~m} / \mathrm{s}$ (526.9 seconds), as it was expected (figure 15). Signs of greater intensity jams were observed, because the elevators capacities and speeds were limited.

Realised results for the sixth scenario showed that the shortest time for evacuation was for the first case and occupant`s speed of $2.4 \mathrm{~m} / \mathrm{s}$ (369 seconds), while the longest evacuation time was for the third case and occupant`s speed of $1.2 \mathrm{~m} / \mathrm{s}$ (589.2 seconds), as it was expected (figure 16). Signs of high intensity jams were observed, mostly because occupants in wheelchairs demanded two other occupants for assistance while occupants in medical beds demanded four other occupants for assistance. Also, the dimensions of wheelchairs and medical beds so as their speed potentials had significant effects on evacuation time increment and jams creating.

Realised results for the seventh scenario showed that the shortest time for evacuation was for the first case and occupant's speed of $2.4 \mathrm{~m} / \mathrm{s}$ (451.6 seconds), while the longest evacuation time was for the third case and occupant's speed of $1.2 \mathrm{~m} / \mathrm{s}$ (754 seconds), as it was expected (figure 17). Signs of very high intensity jams were observed, mostly because occupants in wheelchairs demanded two other occupants for assistance while occupants in medical beds demanded four other occupants for assistance. Also, the dimensions of wheelchairs and medical beds, their speed potentials and dimensions and capacity of emergency stairs had significant effects on evacuation time increment and jams creating.

It is important to note that realised results purported randomly arranged wheelchairs and medical beds, but no more than one wheelchair and one medical bed per floor. It is obvious that evacuation times would be different in case those immobile occupants in wheelchairs and medical beds were concentrated (more wheelchairs and medical beds per floor, especially at lower floors). Also important is to note that occupants had determined speeds and there were no obstacles or alternatives, what is impossible in real situations, especially in presence of stress and panic.

\section{CONCLUSION}

Results realised in this paper showed the great potentials of simulation software usage in evacuation. It is very hard and complicate to calculate evacuation time for residential building with presence of immobile occupants. Furthermore, it is almost impossible to experimentally confirm calculated results for different reasons, such as safety, technical conditions, price etc. Simulation software enables creation of many different scenarios with potentials of many different parameters usage on safe, cheap and fast way. Even in the cases where realised simulation evacuation times and solutions were not satisfied, it is possible to predict, with certain probability, success options for evacuation. This way of potential prediction of evacuation and its introducing with occupants in residential buildings enable calmer, speeder and more effective evacuation. No matter on evacuation reason, it is always better for occupants to be familiar with all potential evacuation routes and procedures in order for success evacuation and human lives protection [10, $11]$.

\section{REFERENCES}

[1] Jevtić B. R, Fire and evacuation in high residential buildings, Facta Universitatis, Working and Environmental Protection, Vol 15, $\mathrm{N}^{\circ} 2$, pp. 123-134, ISSN 0354-804X, Niš, Serbia, 2018.

[2] https://www.google.com/search?q=empire + state + b uilding \& rlz=1C1RLNS_srRS848RS848\&oq=empire + state +building \&aqs $=$ chrome..69i57j0l7.6907j0j7 $\&$ sourceid $=$ chrome \&ie $=U T F-8$.

[3] https://en.wikipedia.org/wiki/List_of_tallest_residen tial_buildings.

[4] https://sr.wikipedia.org/srel/\%D0\%A1\%D0\%BF\%D0\%B8\%D1\%81\%D0\%B $0 \% \mathrm{D} 0 \% \mathrm{BA} \% \mathrm{D} 0 \% \mathrm{BD} \% \mathrm{D} 0 \% \mathrm{~B} 0 \%$

D1\%98\%D0\%B2\%D0\%B8\%D1\%88\%D0\%B8\%D $1 \% 85 \_$D1\%81\%D1\%82\%D1\%80\%D1\%83\%D0 \%BA\%D1\%82\%D1\%83\%D1\%80\%D0\%B0_\%D1 \%83_\%D0\%A1\%D1\%80\%D0\%B1\%D0\%B8\%D1 $\% 98 \% \mathrm{D} 0 \% \mathrm{~B} 8$.

[5] https://www.bestonlineengineeringdegree.com/the10-worst-high-rise-building-collapses-in-history/.

[6] Thunderhead engineering: PyroSim User Manual, USA, 2019.

[7] Jevtić B. R, Simulation of evacuation from mine as a safety measurement, Tehnika, No.1, 2020, pp. 110119, ISSN 0040-2176, UDC: 62(062.2) (497.1), Belgrade, Serbia, 2020.

[8] Wilson L, Planning for evacuating people with disability, International Fire Protection Magazine, Issue 61, pp. 48-50, March 2015.

[9] Jevtić B. R, Sanitary Objects Evacuation With Presence Of Immobile Occupants, Zdravstvena zaštita, Vol 1, pp. 61-68, YU ISSN 03050-3208, UDK numbers: 614.2:351.862.22, Belgrade, Serbia, March 2019.

[10]Chu H. Yu, Wen, J, Yi, M, And Chen, Y.:Emergency Evacuation Simulation and Management Optimization in Urban Residential Communities, Sustainability 11(3):795, DOI: 10.3390/su11030795, 2019.

[11]Kuligowsk, E. and Peacock, R, A Review of Building Evacuation Models, Technical Note 1471, National Institute of standards and technology, 2005. 


\section{REZIME}

\section{EVAKUACIJA IZ STAMBENIH ZGRADA-SIMULACIJA MOGUĆIH EVAKUACIONIH SCENARIJA SA PRISUSTVOM NEPOKRETNIH OSOBA}

Povećanje populacije u gradovima dovodi do nedostatka stambenog prostora. Jedno od mogućih rešenja za ovaj problem je da se izgrade visoke stambene zgrade. Visina ovih objekata, u novije vreme, se kreće od nekoliko desetina do nekoliko stotina metara dok se broj stanovnika kreće od nekoliko stotina do nekoliko hiljada. Iako su ovi objekti izgrađeni po modernism standardima i tehnologijama, sa upotrebom modernih materijala i mašina, problem se mogu dogoditi. Jedan od posebno teških i kompleksnih problema predstavlja evakuaciju stanara zgrade u slučaju neke nesreće. Problem je još teži $i$ komplikovaniji ukoliko su u zgradi ljudi koji su nepokretni ili ljudi sa posebnim potrebama. Moguće rešenje za ovaj problem može biti upotreba simulacionog softvera. Ovaj rad je napisan da prikaže upotrebu simulacionog softvera Pathfinder u proračunu evakuacionih vremena za različite evakuacione scenarije, bez prisustva nepokretnih osoba, sa prisustvom nepokretnih osoba od $5 \%$ u odnosu na ukupan broj okupanata i sa prisustvom nepokretnih osoba od $10 \%$ u odnosu na ukupan broj okupanata

Ključne reči: evakuacija, stanar, nepokretan, scenario 